書

クラーク：人口地理学

Clarke, J.I. (1968) : Population geography

Pergamon Press 164 pp.

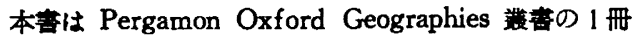
として刊行されたものて，蕏は英国ダー八ム大学に策 をおく地理学者である。初版は1965 年であるが,この

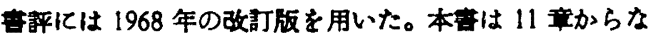
り，以下童をおって简単に内容を紹介する。

1 「人口地理学とは何汃で人口地理学の目的を， 欧米およびソ速の地理学者の見解を索にした上て，「人

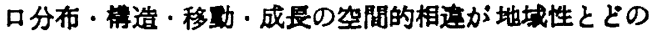
ように關保している加」研究することにあるとしてい ろのは妥当な考え方といえよう。ここていまた，人口地 理学の研究にとって人口学の基硴的知誠力; 不可久である ことが強调されている。2「データのタイフと問题」て は，人口統計の不正碇さの要因，人口静能統計と功態統 计，センサスの現在地主美と常住地主義，合采国におけ

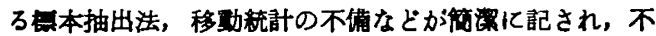
正碇・不揞いなデータによる安易な計算・考察の危除儿 ついて述へている。3「世界の人口分布」に影徱を气え ろ要素として，大陸性と島鮧性・高度・尤伏・気候・土

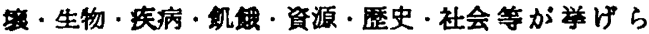
れ，人口分布との閣保か論しられる。人口分布は各相の 要素の被嚾なからみ合いによって規定されることから， 単純な決定論的推测をいましめている。

4 「人口密度と分布の测定」ては，著者かかつて研究 を行なった Persons per roomをる含めた各程の人口 密度の得失を論し，分布の湘定については，人口更心 人口中心・人口ポテンシャル・ローレンツ曲線の实例や 迹用例がされており，また Wright, J. K., Clark, P. J., Evans, F.C., Barnes, J.A., Robinson, A.H. 等の諸業鹳か唖領よく䂏介されている。5「都市およひ

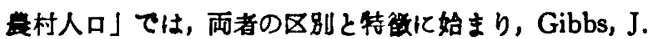
P. の都市化段階锐，都市人口の㮌位法則，Christaller， W.の莱统，Clark，C.の都市人口密度の法則， Demangeon, A. の古典的な集落分散度の測定法の釈介 が行なかれる。

6 「人口維造のパターン」は，本言中もっとも多くの

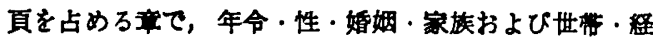

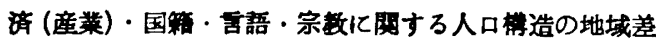

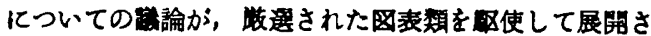
れる。

7 「出生本のパターン」は次の第 8 章と並んて，從来 の地理学てはあまり注目されなかった分野であるか，本 专で独立した章を与えられている。ここでは各程の出 生本の算出法，乙の得先，出生本の世界的バターン，英 国を例とした出生柬の推移，差别出生束について还べ ろ。8「死亡本のハターン」は第7章とほほ同じ輠成
評

で，各馧の死亡中，死亡中のパターンと推移，羑別死亡 束，死因等が英国の例を主として述へられる。数程の疾 病地因が揭载されており，これはこの方面の地理学的研 究が淮んている英国地理学界の强味てあろう。

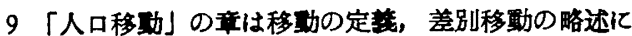
つふいて，国内移勤と国際移功を报っている。10「人口 成長」ては，人口再生産本の測定法，人口部画，人口理 睔，人口政策，人口成長の諸段階，後進国におけ万第 2

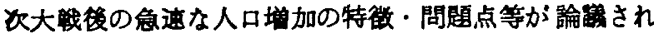
ろ。11「人口と资源」では取適人口・過勫人口・過少人 口問題等の他に，世界人口のすう等についての諸学者の 見解が之められている。第 $10 １ 1$ 章はともに地理学者 にとってはいわばなしみの薄い研究分野であるか，著者 は主要な文献からそのエキスをうまくとり出し，問題点 を解りやすく解説している。

以上内容を简単に紹介したか，その橦成からも，本㶳 は現在の人口地理学の諸分野を汪注全面的に包括してい ろ。近年人口地理学の著害証英語版们限っても数稙発行 されていろが，あるるのは本䁈論・方法論の展用にいそ

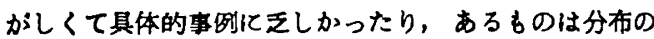
記戟か中心て人口そのbのの活勤かなおさりにされた り，またあるちのは文化人類学との区別が困噰な内容て あったりして，近年の人口地理学の進歩のみならず地理 学の分野あるいは人口学の進歩とも歩調があっていない といえよう。こういった悄況の中て，本害の若者は人口

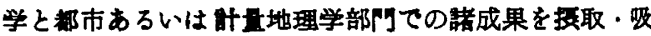
収して，これを巧みに人口地理学の体系の中に租みこん ていろ。それをわずか170 頁足らずの小冊子にまとめあ けた著者の力貫を高く評価したい。

本害には 1963 年经までの人地理学とその関連分野

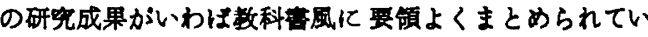
ろのて，人口地理学化進もうとする人たちにとっては恰 好のテキストであり，地理学の他の分野の人か人口地理 学の研究水潭を知ろのにも有用である。（小笠原節夫）

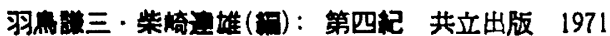
348 具

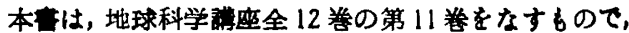
1. 第四紀学の性格，2. 水河と水河時代，3，気候变化

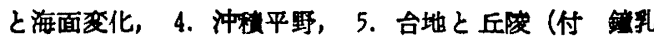

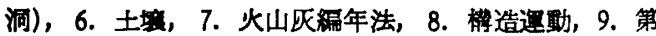
四紀の生物地理，10. 人類の発展と日本の石器時代，以 上10章よりなる。各草は，4つの童が2名，他は1名 の，それそれ地资学・地理学・土淁学・古生物学・人数 学の各要塛家により執等されている。

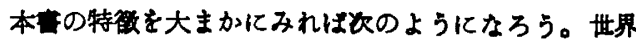
の第四紀研究を紹介しつつ，異富になった本邦の例をb り迈み，各分野の今まての知見を総括していること。ま 
た，第 1章の中で明確にビジョンが示されているよう に，第四紀研究の意意を，生産〜応用に対する・地䝷学 に与えろ・趿植物学や土壤学, 地球化学などに与える・ 考古学〜人類学に与えろ・地学教育に与えろ，それそれ の意義として展開し，さらに今後の方向として，自然史 的研究・懪境科学的研究に大別して課題を論ずる，こん な所に特锴がみられよう。

本邦においては，評者の知る限り「第四紀」という書 物が，大塚弥之助 (1931，岩波鿁座) - 鹿間時夫 (1952， 民科地団研部会) - 小林国夫 (1962, 地団研，上巻のみ) によりまとられており，似たものとしては，正雄に よろ「後氷期の世界」(1954) とその増訂版「氷河時代の 世界」(1970)とか刊行されている。

本害の発行にあたり，これらを回靨しつつ此較してみ ろのも意味があると考えられる。本書といまあげた5つ の苦物のちがいは，分担執筆と単独執筆との大きなちが いはあるが，これはさておき年代頋に追ってみろと，や はり大きな流れが感じられる。䄪 40 年前の大塚による ものは，地中海の第四系・段丘のドベレーの編年の紹介 から入り，海转・陸㜞動物群，植物群，人颣関する資 料, 気候変化史，これらにもとつく考祭をヨーロッパて の研究の紹介と当時の日本での知見を坮する形で進 め, ついで地形学的方法と造棈史・火山活勒史にもとつ く考察を，関東その他日本の例喻及していろ。これ は，主として当時の新生代の地賀学の㑭点から，ヨーロ ッパの知識を吸収しつつ，かつ，ようやく集積し始まっ た本邦の第四紀の地形・地貿・古生物についての矢部・

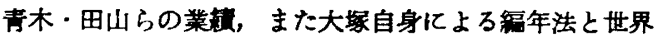
との対比の志向，これらを明瞵に示すものであった。

大塚がこの本を執筆した頃には，八木貞助(1928)の信 州の洪程層についての論文や，小沢倿明(1926)の大雨期 に閣するものなどあり，アジア大陸・台流また南洋諸岛 の地質・地形・古生物の知見か増えつつあった。しかし

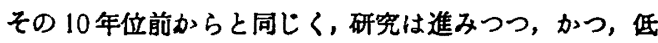
位置水河の存否の論争で示されろような，浮動の多い時 期でちあった。

その後戦争があり，海外の研究を知ろ機会の少なくな ったまま，しかし，ようやく団体研究の成果の向上を目 指す段階に，戦前のアジアの資料を活用しつつ棇括され たのが鹿間(1952)の「第四紀」とみられよう。とくに彼 の表阿である古生物に閶する記述が多いか，棇説・気候 史・生物史 ·人類史・東要大陸の第四系・日本の第四系 一海成層・陸成虽一という章立てで，戦中の空白を埋め ようとするかのように茟かれている。

これに対し，小林 (1962) の「第四紀(上)」は，1，第 四紀の概念，2. 水河性海面变動仮説，3. 下末吉海進， 4. 後水期海進，5. 地形面という各章で棈成され一下 巻か執筆されないままとなっているのて，残念なことに 全般の企画は分らないか－一団体研究て明らかにされた 事实にもとつきつつ，本邦の地形・地貫 ·土坛・人類遗 物をグレーシャル・ユースタシー説と關連させ，また，

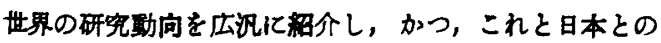

比較を行う意図を明瞭に示している。鹿間 (1952) が地 質古生物学的手法中心だったのに対し，小林のこれは， 矢部加ら大塚に至る地形面の第四紀研究における重要性 を再びとり上げ，なお，段丘面や侵蝕面の世界的視野で 見ることの必要性を常識化したものであった。

これら，以前の「第四紀」に対し，関東ローム団研 (1965)：「関東口ーム」(築地書館)，第四紀 総合研究会 (1969):「日本の第四系」(地団研) などに示される最近 の日本の第四紀研究の進歩をうけて出された本書は，当 然のことながら内容は豊富である。各章は，それそれが 共同研究や団体研究を行ないつつ研究を進めて来た人迲 だけに，更門的な厚みと視野の広さをにじみ出させてい ろ。

しかし難点もないではない。企画されてから時間がた ち，榑成し方に再検討を加えたい気持 もあろが，現時点 て出版し，海底や古地磁気学による首序の対比・同定法 は久けろにしても一応まとめ，次の段階へのステッフと したかった：つまり，過渡的段階を反映する面か強いて あろう，と編者の序文にある。この点は常にやむをえな いこととして許されよう。だが，評者にとっては分担執 筆に起因するかと思われろ久陮加目につく。生き生きと して，つまり今までの研究法の経過・成果を要約しつ つ，更にこれからの研究者に刺贼を与えろような書き方 の所 (その好例仙，7. 火山灰編年法）と，いわゆろ教科 㶳風の章とが混在するのである。しかも，世界的視野を ひらかせてくれるものと，全く日本の例を主とし，地䆩 誌としての「日本の第四系」の事項別各論といった風な 所もみられろのである。

教科害よりも副哂本の方か；，本当の勉强の来材になる ことがある。先記した湊 $(1954 ， 1970)$ の 2 落が，形式と しては副副本的読物の憱成をとりながら，同氏と井尻と の共落になる岩波新营と共に，研究法・成果の要約・今 後の研究への示唆を与えてくれるものであることを忘れ ろべきでないと思われる。

䛍座は分担執筆で行なえば，とくにその輠成や内容 で，並大低でない苦学を味わうものであろう。とくにア イティアや手法が多様で㚆化しつつあろ分野のものにあ っては。しかし，いわゆろ数科䓢風な用語の説明などは 他范や辞典にゆつり，現時点の研究の成果の維列的リス トアッフに徽するか，あるいは展望や示唆を多く含み後 目役立つか(この双方が望ましいが），どちらかに主点 を置くべきではなかったろうか。

（若生连夫）

\section{大森界重・茂木昭夫・星野通平：浅海地觉学 海} 洋科学基磷講座 7 東海大学出版会 1971 445 頁

海洋学ということばで総括されていた学問分野は現在 ひじょうに広筙に拡大し，自然科学の各分野がそれぞれ 海洋を対象とする分科をすつに至った。この諢座は，日 本における海洋に関する自然科学の成果をまとめて示そ うとするもので, $12+1$ 巻よりなる。

地形学・地賀学に関しては 2 巻があてられ，それそれ

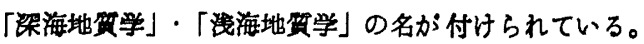


「深海地资学」る既に刊行されているがここては最近 出版された「浅海地筫学」について紹介しょう。

「浅海地䁈学」は大きく3編化分かれ，潮間带・汀線

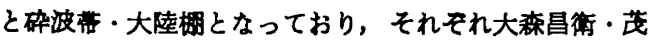
木昭夫・星野通平の執筆する所てある。初めの 2 編は海 岸に関するちのであるか，大森の第 1 編は茂木の第 2 編 よりも挟い部分を报っており，より地筫的であるといえ ろ。茂木の第 2 編は海岸地形といってもよい内容てあ ろ。

大森の第 1 編・潮間需 は漓湖線と低湖楾にはさまれ ろ部分をとり报っている。ここは阹上の学力と海岸の学 力が交代頨合する所でる。まず現在の湖間带について

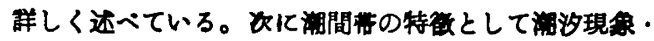
海水およびこれらが生物相にどういう影を与えている かということをとり上げる。さらに地学学にとって而

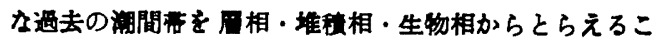
とを群しく湌时している。

茂木の第 2 編・汀緗と碎波满 は海岸地形の用語・海

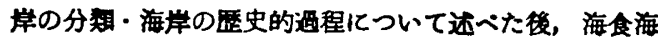

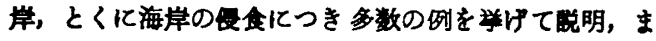

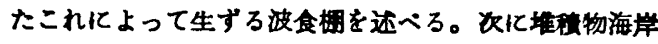

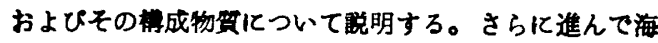
浜断面に上万海浜型を述へ，日本におけろ分類を詳説す

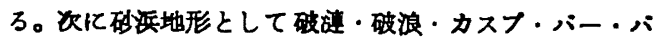
リアを述へろ。誌いて海岸值角な方向と平行な方向と

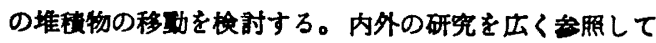
著者自身の研究を中心にまとめた，海岸地形の侵れた概 括てある。

星等の第 3 編・大陸楜 は現在問题の多い大陸佣の地 形・地票についてまとめたもので，大陸柯の定姜に始ま

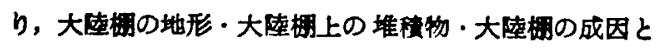

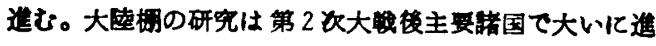

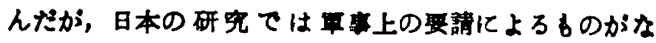
くまた资料の非公䁌がいことが指捅されている。地

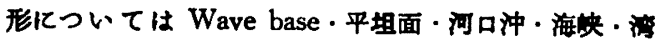
の地形について䍩しく述へた後，地形变化をとり举げ

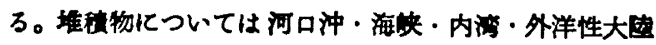

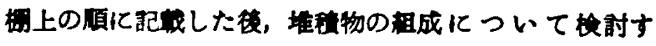

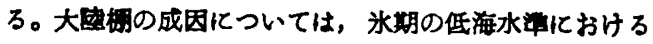

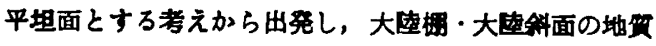

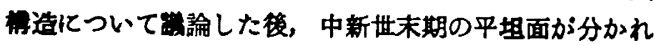

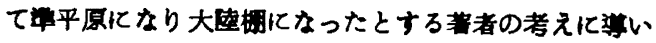
ている。

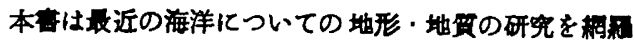
して，その進歩の状況を迢硣に锐明している。日本の地 形・地面の研究は海洋に向かってきたけれどる，まだ研 完者の数は限られている。海洋の地形・地䨘の研究者は ますます必畏になってくろ。本書がきき策内者の役をつ とめるちのと思われる。

(西村言助)

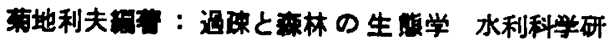
完所 1971395 頁
本满の約半分は菊地利夫が盇き，他の半分を千莱德

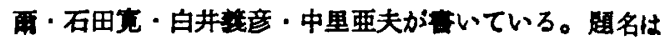
苦心したもののようであるか，电力的なるのに思える。 日本の経済成長のかげになった過㻋地域の地理学といれ ろ内容であるか，萧者たちの目荎した所はそれ以上の所 にあったと思われ，それが生檪学として表現されたのて あろう。いわは眖地理学を目差したるのといえる。ただ 気になることは，森林の生吿学といえばまったく植物生

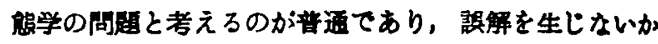
ということである。

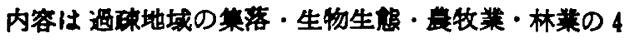
章と開発の1章とからなる。生物生愁付千莱の執管てあ り，费牧業は石田・白井・中里の分担執簕であり，他は 全部菊地の執筆である。

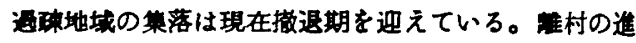
行ととるに機能の久陥を生し，集落の維持が困榷とな

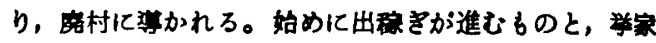
村へいきなり入ろるのとがあるというのか従来の考え であった。菊地仕各地の調査に基いていろいろな型を学

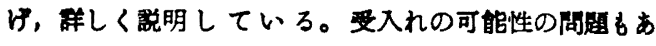
ろ。集落内部に栍をひきとめろ力があるかどらかが

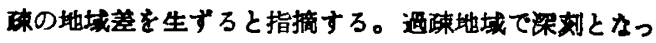

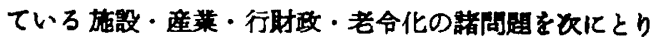

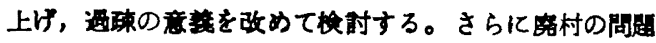
に進み，その事例をげる。過䂾地域においてい中心集 落は発展していることを事例を举げて指摘し，最後儿集 落再編成の計画と实施につき，主として岩手姐沢内村の 甽注おてて述べる。

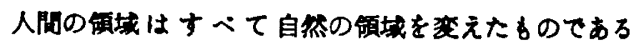
か，遇体地域は人閥領域の先端部であり，過体か進行す

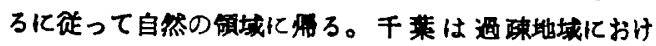
ろ、人間をる含めた生物生的的展望を行なっている。山 地に人間か入っていったことの意味からほりかえし，递

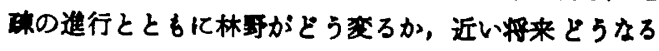

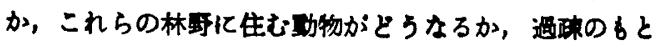
て山地の保全が可能てあろかなと，具体的な多数の例を 举げて镜明し，明快な意見を逨へている。

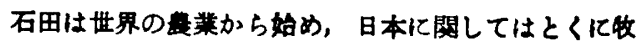
音について，東北と中国地方とを根本にして過䂾との関 保老锒等する。

白井は東北地方のうち，とくに岩手紫におけろ费萧の

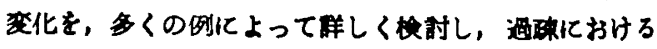

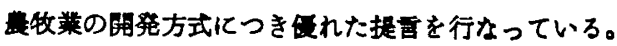

中里は中国山地過㻋町村の音産の实愁沉いて述へて いる。稻作と肉用牛に比再がかかってき，共同放牧から 個人呚场人と進んでいく状㳳を道確にとらえている。

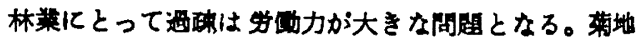
は歴史地理学的考家を，片品川流城と中国山地の吉和村

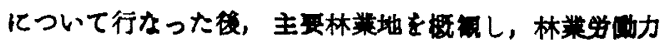
の成题に移る。次に北上山地を中心に山地土地利用の再 編成を考え，棵林の非経済的利用を还へろ。

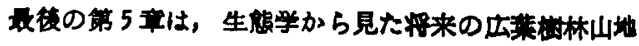


の開発と題する ののて，始めに生態系の䛨しい説明があ

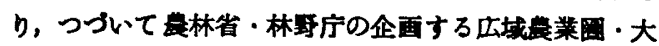

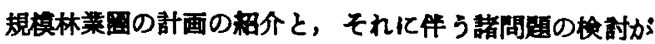
なされている。

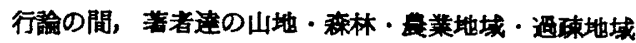
に対する傎かしみ出しており，心をうたれる所が多 い。帛砵地城をとりあつかった害物として出色のるのて あろう。

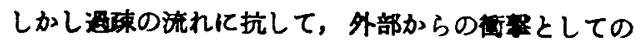
压域晨莱国・大規模林業の計画が地域にどれだけ定着す ろであろらか。現在の開放娃娍（はしがきの解放经済は 筆の俱りであろう)の中て，日本の第一飞産萧をより一層 開発するだにどれだけの投筧がされ得るだろうか。

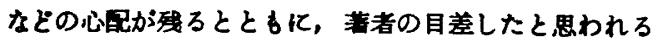
地理学以上のものが何であったか, field geographer しての記述以外の部分が官庁サイトに梁入りしていろの てはないか、などの点につき，いつか数示を得たいと思 うのであ。

(西村㫷助)

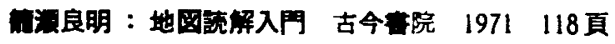

1953 年「地因の楛み方」Map Reading 出して以来,

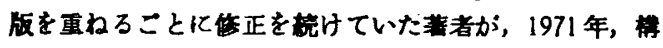
想を新たにして「地図読解入阿」Map Interpretation と 題する本書を世䎲問うた。この 20 年近くの間における 日本各地の地域变化か＼cjkstart地罒の形て記飹されているととる に, 日本におけろ地図の進歩をる示するのとして，興制 染くかつ楽しく読むことができた。

屈状地・自然是防と後背低湿地・三角州・海岸・段兵 合地・谷と山地・断屏地形・火山・さんこ磷という地形 を主とした部分と，集落の発達・都市の発達・住居表示 ・第一次産莱地域など・第二次産莱地域など・测光地域 なとという人文地理を主とした部分てなっており，前者

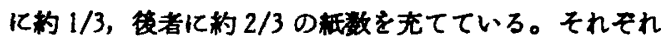
の愐目は数個所の実例で示されていろ。1 個所は 1 頁あ ろいは 2 頁で収まるよう亿考虑されており，地四の切り 方・縮尺などについての苦心の汪かに，空中写基・视明
四・鄫明文など 余白一ばいに入ろようにする苦心が大き かったであろう。さらに何よりる実例とすべき地四の選

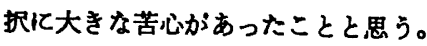

地罒の選択には分りやすいということを基靯にして 行ったとあるか，この点はかなり成功しているように思 う。この基浬を徽底すると説明文などはほとんど不要に なろのであろか，地図の讜解はそんなに容易なことでは ない。萧者が先達として自分の就解の結果を述べたとい らのか説明文であうっこれがなければ，あるいは見逃 すかる知れないというようなことをよく指摘してあり，

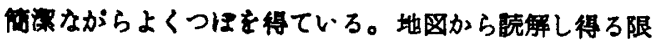
度以上のことを就解し得たように眍述してはいけないと

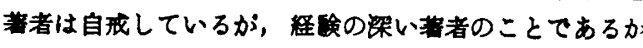
ら思わず害いた所がまま見当る。しかし地図の放解仙そ れだけで止まろるのでなく，出発点となるべきすのであ ろということを示すことには役立とう。つまり著者のよ うな説明かできなくても，地図の珫解としては充分な場 合が多いということである。

若干翌のついた所をつけ加えておこう。柬引図に 71 というのが凮山柰・山形罧にあるがこれは削除するのを 忘れたのであろう。2の筧考山地東管の扇状地の傾斜か; 急なことか，1の神戸原䲩状地の等高線と間隔をくらへ ろとよく分るとあるが，樎尺を考虑してもよく分らな い。またこの扇状地の果樹園として利用されやすい自然 的条件か理解されるとあるか，これも㖵解である。17の 面解析度は面開析度としたい。20の，北の河川にくらへ て南の河川の堆程力が袁えたためとの考えは，興味をひ くが、汪か䎲も考元るべ条件があると思う。84-3赫 印の方向に押流されたとあるか，赤矢印俚見当らない。

地四山重要な情報源である。地図を続解する能力とい うのは，すなわち地図から倩報をひき出す能力である。 このような能力は経稌をみ亚るることによって得られ ろ。本害はこのような経峆を集中的に与えるるのであ

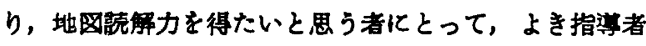
となるであろう。

(西村 嘉助)

\section{紹}

\section{ソ遣科学アカテミー：現世の外的地形学力}

Academy of Sciences of the USSR (1970): Present exogenic geomorphic processes Publishing House NAUKA, Moscow 227 ps.

ソ建科学アカテミー，地形委貝会の第 7 回年会のプロ シーティングス。露文化英文要旨を付した 27 報告より なる。紹介者の敔学力から本文にるとずいては行なえな いがるともとそれそれが短い制文なので，要旨徒っ て研究勤向の大要を紹介する。

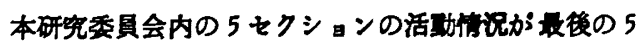

帮文で述べられている：「現在の外的営力の研究法（四化

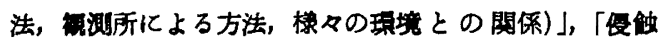

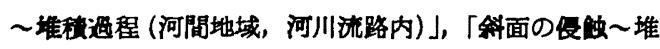

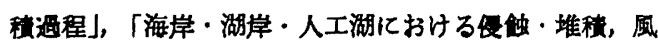
成・カルスト・周水河各過程」，「現在の外的営力にかか わろ取近のテクトニック・ムーフメント」—これら各 セクションの研究倩況の简単な発素予告。

他の 22 報告を地形ないし 過程の租類で分けてみると 以下のようである：I.P.ダラシモフの第1番目の報告を 含め，5つか現在までの知見・今後のための方法（阿 